This article is licensed under the Creative Commons Attribution-NonCommercial 4.0 International License (CC BY-NC) (http://www.karger.com/Services/OpenAccessLicense). Usage and distribution for commercial purposes requires written permission.

\title{
Signet Ring Cell Carcinoma of the Ampulla of Vater: A Rare Histopathological Variant
}

\author{
Guus W. de Klein ${ }^{a}$ Joop van Baarlen ${ }^{b} \quad$ Leonie J. Mekenkamp ${ }^{c}$ \\ Mike S.L. Liem ${ }^{a}$ Joost M. Klaase ${ }^{d}$ \\ aDepartment of Surgery, Medisch Spectrum Twente, Enschede, The Netherlands; \\ bLaboratorium Pathologie Oost-Nederland (LabPON), Hengelo, The Netherlands; \\ 'Department of Internal Medicine, Medisch Spectrum Twente, Enschede, The Netherlands; \\ dDepartment of Surgery, Universitair Medisch Centrum Groningen, \\ Groningen, The Netherlands
}

\section{Keywords}

Periampullary carcinoma $\cdot$ Signet ring cell carcinoma $\cdot$ Jaundice

\begin{abstract}
Signet ring cell carcinoma (SRCC) of the ampulla of Vater is an extremely rare tumor. Our case describes a 45-year-old female presenting with jaundice and pruritus. Computed tomography, endoscopy, and endoscopic retrograde cholangiopancreatography showed a tumor of the ampulla of Vater without distant metastasis. Histological biopsy confirmed a malignant tumor with SRCC characteristics and immunohistochemical staining revealed a mixed type profile (both intestinal and pancreatobiliary characteristics). A pylorus-preserving pancreatoduodenectomy was performed and the patient recovered without complications. Pathology results concluded a pT2N0 ampullary SRCC. SRCC of the ampulla of Vater is known to be highly malignant. After 13 months of follow-up, our patient showed no signs of recurrence.




\section{Case Reports in Gastroenterology}

Case Rep Gastroenterol 2018;12:194-201

DOI: $10.1159 / 000488903$

(C) 2018 The Author(s). Published by S. Karger AG, Basel www.karger.com/crg

de Klein et al.: Signet Ring Cell Carcinoma of the Ampulla of Vater

\section{Introduction}

The ampulla of Vater, also known as the hepatopancreatic duct, is formed by the union of the main pancreatic duct and the common bile duct. At this confluence, the epithelium of the biliary, pancreatic and intestinal system merges. Therefore, the ampulla of Vater is considered an interesting area regarding histopathology. Tumors in the region of the ampulla, or periampullary tumors, represent only a small portion of all gastrointestinal tumors. Especially true ampullary cancers are rare, with a reported population incidence of 2-6 per million [1]. True ampullary tumors have better prognoses than other periampullary tumors in general, as well as a higher resectability rate [2]. Most ampullary tumors are adenocarcinomas with intestinal or pancreatobiliary origin, although several histopathologic variants have been described. One of those variants is the highly malignant signet ring cell carcinoma (SRCC).

SRCC is predominantly found in gastric tumors [3], but it is also found in various tumors including tumors of the gastrointestinal tract, hepato-pancreato-biliary system, and urogenital system. This adenocarcinoma subtype is thought to be associated with poor prognosis in advanced cancer, and is thought to be less chemosensitive than non-SRCC [4]. Very few cases of SRCC of the ampulla of Vater are described. Less is known about the pathogenesis, treatment, and outcome of this infrequent histologic subtype. Immunohistochemical staining might be used for further investigation of origin and characteristics of the tumor [5]. This report adds a case of ampullary SRCC to the few known cases.

\section{Case Report}

A 45-year-old female presented at the emergency department with jaundice and pruritus. Apart from a hepatitis B infection in the past, the patient was healthy and her history and physical examination gave no further clues. Laboratory results showed high levels of total bilirubin $(83 \mu \mathrm{mol} / \mathrm{L}$ at first presentation, increasing to levels above $500 \mu \mathrm{mol} / \mathrm{L}$ within 2 weeks). Computed tomography showed a double duct sign (Fig. 1). Endoscopic retrograde cholangiopancreatography was performed, which showed a swollen ampulla of Vater suspicious for malignancy. A histological biopsy showed an adenocarcinoma with the characteristics of signet ring cells (Fig. 2). Immunohistochemical staining showed that the signet ring cells were positive for CK20, CK19, MUC-1 (weak), MUC-2, CDX-2, and DPC-4, and negative for CK7, ER, GCDFP, and MUC-5ac (Fig. 3).

In the absence of metastatic disease, a pylorus-preserving pancreatoduodenectomy (PPPD) was performed. Histopathological findings showed an SRCC of $1.2 \mathrm{~cm}$, poorly differentiated, without peripancreatic invasion, lymph node involvement, angioinvasion, or perineural invasion (Fig. 2, 3). The resection margins were clear of tumor cells, minimal margin to the tumor was $1.0 \mathrm{~cm}$. Fourteen lymph nodes were identified without metastasis. The TNM classification according to the International Union Against Cancer (7th edition) was pT2N0M0.

Our patient recovered well from surgery, and no adjuvant treatment was given. After 13 months of follow-up, there was no evidence of recurrence. 


\section{Case Reports in Gastroenterology}

Case Rep Gastroenterol 2018;12:194-201

DOI: $10.1159 / 000488903$

(C) 2018 The Author(s). Published by S. Karger AG, Basel www.karger.com/crg

de Klein et al.: Signet Ring Cell Carcinoma of the Ampulla of Vater

\section{Discussion}

This report presents a patient with an early-stage SRCC of the ampulla of Vater, with no signs of recurrence after a PPPD and 13 months of follow-up.

Less is known about the pathogenesis of SRCC. Signet ring cells are round-shaped and contain large vacuoles. They form highly malignant and invasive tumors, with dedifferentiated cells without cell-cell interaction. Fukui [6] described a mechanism of mutations in cells with a preexistent malignant phenotype, resulting in the formation of signet ring cells. SRCC is defined as the occurrence of more than $50 \%$ signet ring cells.

Carcinoma of the ampulla of Vater accounts for $0.2 \%$ of all gastrointestinal malignancies and $<6 \%$ of all periampullary cancers [7]. Only 37 cases of SRCC of the ampulla have been described so far, of which 27 in the English literature [8-11] (Table 1). The patient in the presented case is relatively young, and only 5 studies reported younger patients than our patient. The median age described in the literature is 60 years. The disease is described in male and female patients, although there is a slight predominance in male patients.

Ampullary SRCC may be further divided into intestinal type (I), pancreatobiliary type (PB), gastric type, and mixed type [5, 12]. This classification is based on immunohistochemical staining. Expression of CK7, CK19, and MUC-1 is associated with PB-type, expression of CK20, MUC-2, and CDX-2 is associated with I-type, whereas co-expression of MUC-5ac and MUC-6 is associated with gastric type. Our case showed an immunohistochemical profile compatible with I-type SRCC, but it also shows the PB-type (CK19 expression and weak expression of MUC-2). This is a mixed type of SRCC, which has only been previously described once [5].

Like all periampullary tumors, surgery remains the cornerstone of treatment. In our case, PPPD was performed. The Dutch guideline does not recommend adjuvant chemotherapy for ampullary tumors in general [13]. Different case reports of adding 5-fluorouracil or gemcitabine/cisplatin have been described, with variable results $[5,10]$.

For metastatic ampullary tumors, chemotherapy is given and the subtype of the tumor determines the regime (PB-type vs. I-type). However, in the case of SRCC of the ampulla of Vater the response is unknown. The response to chemotherapy of SRCC, which is mostly studied in gastric, esophageal, and colorectal cancer, is thought to be less [4].

Median overall survival rates of 24.9 months are described with a range of 6-132 months [8]. This compared to 37 months, which is reported for resected ampullary carcinoma in general [14]. Only a handful of cases report a survival of more than 5 years, although follow-up time is often limited at the time of publication. Lymph node invasion appears to be the most important prognostic factor $[12,15]$. Also an I-type SRCC might have a better prognosis than a PB-type SRCC [5]. Mixed type SRCC is associated with poorer prognosis, although follow-up is too short in our case.

In conclusion, SRCC of the ampulla of Vater is an extremely rare gastrointestinal tumor; this report adds a 38th case.

\section{Acknowledgement}

No funding was received. 


\section{Case Reports in Gastroenterology}

Case Rep Gastroenterol 2018;12:194-201

DOI: $10.1159 / 00048890$

(c) 2018 The Author(s). Published by S. Karger AG, Base www.karger.com/crg

de Klein et al.: Signet Ring Cell Carcinoma of the Ampulla of Vater

\section{Statement of Ethics}

The authors have no ethical conflicts to disclose.

\section{Disclosure Statement}

The authors have no potential conflicts of interest.

\section{References}

1 Benhamiche AM, Jouve JL, Manfredi S, Prost P, Isambert N, Faivre J. Cancer of the ampulla of Vater: results of a 20-year population-based study. Eur J Gastroenterol Hepatol. 2000 Jan;12(1):75-9.

2 Morris-Stiff G, Alabraba E, Tan YM, Shapey I, Bhati C, Tanniere P et al. Assessment of survival advantage in ampullary carcinoma in relation to tumour biology and morphology. Eur J Surg Oncol. 2009 Jul;35(7):74650.

3 el-Zimaity HM, Itani K, Graham DY. Early diagnosis of signet ring cell carcinoma of the stomach: role of the Genta stain. J Clin Pathol. 1997 Oct;50(10):867-8.

4 Pernot S, Voron T, Perkins G, Lagorce-Pages C, Berger A, Taieb J. Signet-ring cell carcinoma of the stomach: impact on prognosis and specific therapeutic challenge. World J Gastroenterol. 2015 Oct;21(40):11428-38.

5 Wen X, Wu W, Wang B, Yao H, Teng X. Signet ring cell carcinoma of the ampulla of Vater: immunophenotype and differentiation. Oncol Lett. 2014 Oct;8(4):1687-92.

6 Fukui Y. Mechanisms behind signet ring cell carcinoma formation. Biochem Biophys Res Commun. 2014 Aug;450(4):1231-3.

7 Howe JR, Klimstra DS, Moccia RD, Conlon KC, Brennan MF. Factors predictive of survival in ampullary carcinoma. Ann Surg. 1998 Jul;228(1):87-94.

8 Damania R, Weaver J, Cocieru A. Signet Ring Cell Carcinoma of the Ampulla of Vater with Early Development of Bone Metastasis: Case Report and Review of the Rare Malignancy. J Gastrointest Cancer. 2016 Mar;47(1):89-92.

9 Ushida Y, Hiramatsu K, Saeki S, Amemiya T, Goto H, Arai T. Poorly differentiated adenocarcinoma with signet-ring cells in duodenal papilla: a case report. Surg Case Rep 2017 Dec;3(1):14.

10 Wakasugi M, Tanemura M, Furukawa K, Murata M, Miyazaki M, Oshita M et al. Signet ring cell carcinoma of the ampulla of vater: report of a case and a review of the literature. Int J Surg Case Rep. 2015;12:108-11.

11 Yuza K, Sakata J, Soma D, Ando T, Hirose Y, Ishikawa H et al. Signet-Ring Cell Carcinoma of the Ampulla of Vater - report of a Case. Gan To Kagaku Ryoho. 2015 Nov;42(12):1767-9.

12 de Paiva Haddad LB, Patzina RA, Penteado S, Montagnini AL, da Cunha JE, Machado MC et al. Lymph node involvement and not the histophatologic subtype is correlated with outcome after resection of adenocarcinoma of the ampulla of vater. J Gastrointest Surg. 2010 Apr;14(4):719-28.

13 Landelijke werkgroep Gastro intestinale tumoren. Oncoline, pancreascarcinoom. 2011 [cited 2017 Dec 3]. Available from: www.oncoline.nl/pancreascarcinoom.

14 Klein F, Jacob D, Bahra M, Pelzer U, Puhl G, Krannich A et al. Prognostic factors for long-term survival in patients with ampullary carcinoma: the results of a 15-year observation period after pancreaticoduodenectomy. HPB Surg. 2014;2014:970234.

15 Hara T, Kawashima H, Ishigooka M, Kashiyama M, Takanashi S, Hosokawa Y. Signet-ring-cell carcinoma of the ampulla of Vater: a case report. Hepatogastroenterology. 2002 Mar-Apr;49(44):561-3.

16 Gardner HA, Matthews J, Ciano PS. A signet-ring cell carcinoma of the ampulla of vater. Arch Pathol Lab Med. 1990;114(10):1071-2.

17 Tseng LJ, Jao YT, Mo LR. Signet ring cell carcinoma of major papilla. Gastrointest Endosc. 2002;56(5):733.

18 Eriguchi N, Aoyagi S, Jimi A. Signet-ring cell carcinoma of the ampulla of vater: report of a case. Surg Today. 2003;33(6):467-9.

19 Li L, Chen QH, Sullivan JD, Breuer FU. Signet-ring cell carcinoma of the ampulla of Vater. Ann Clin Lab Sci. 2004;34(4):471-5.

20 Ramia JM, Mansilla A, Villar J, Muffak K, Garrote D, Ferron JA. Signet-ring-cell carcinoma of the Vater's ampulla. JOP. 2004;5(6):495-7. 


\section{Case Reports in Gastroenterology}

\begin{tabular}{l|l}
\hline Case Rep Gastroenterol 2018;12:194-201 \\
\hline DOI: 10.1159/000488903 & $\begin{array}{l}\text { @ 2018 The Author(s). Published by S. Karger AG, Basel } \\
\text { www.karger.com/crg }\end{array}$ \\
\hline
\end{tabular}

de Klein et al.: Signet Ring Cell Carcinoma of the Ampulla of Vater

21 Fang CL, Chu JS, Hsieh MC, Wu MS. Signet-ring cell carcinoma of the ampulla of Vater. J Formos Med Assoc. 2004 Oct;103(10):793-6.

22 Bloomston M, Walker M, Frankel WL. Radical resection in signet ring carcinoma of the ampulla of Vater: report of an 11-year survivor. Am Surg. 2006 Feb;72(2):193-5.

23 Akatsu T, Aiura K, Takahashi S, Kameyama K, Kitajima M, Kitagawa Y. Signet-ring cell carcinoma of the ampulla of Vater: report of a case. Surg Today. 2007;37(12):1110-4.

24 Gao JM, Tang SS, Fu W, Fan R. Signet-ring cell carcinoma of ampulla of Vater: contrast-enhanced ultrasound findings. World J Gastroenterol. 2009;15(7):888-91.

25 Ishibashi Y, Ito Y, Omori K, Wakabayashi K. Signet ring cell carcinoma of the ampulla of vater. A case report. JOP. 2009;10(6):690-3.

26 Gheza F, Cervi E, Pulcini G et al. Signet ring cell carcinoma of the ampulla of Vater: demonstration of a pancreatobiliary origin. Pancreas. 2011 Jul;40(5):791-3.

27 Paplomata E, Wilfong L. Signet ring cell carcinoma of the ampulla of Vater with leptomeningeal metastases: a case report. J Clin Oncol. 2011 Jul;29(21):e627-9.

28 Maekawa H, Sakurada M, Orita H, Sato K. Signet-ring cell carcinoma co-existing with adenocarcinoma of the ampulla of vater. A case report. JOP. 2011 Mar 9;12(2):162-6.

29 Lesquereux-Martinez L, Fernandez-Perez A, Bustamante-Montalvo M. Signet ring cell adenocarcinoma of the ampulla of Vater: a rare pathology. Rev Esp Enferm Dig. 2012 Sep;104(9):501-2.

30 Daoudi K, El Haoudi K, Bouyahia N et al. Signet ring cell carcinoma of the vater's ampulla: a very rare malignancy. Case Rep Oncol Med. 2012;2012:402798.

31 Acharya MN, Panagiotopoulos N, Cohen P, Ahmad R, Jiao LR. Poorly-differentiated signet-ring cell carcinoma of the ampulla of vater: report of a rare malignancy. JOP. 2013 Mar 10;14(2):190-4.
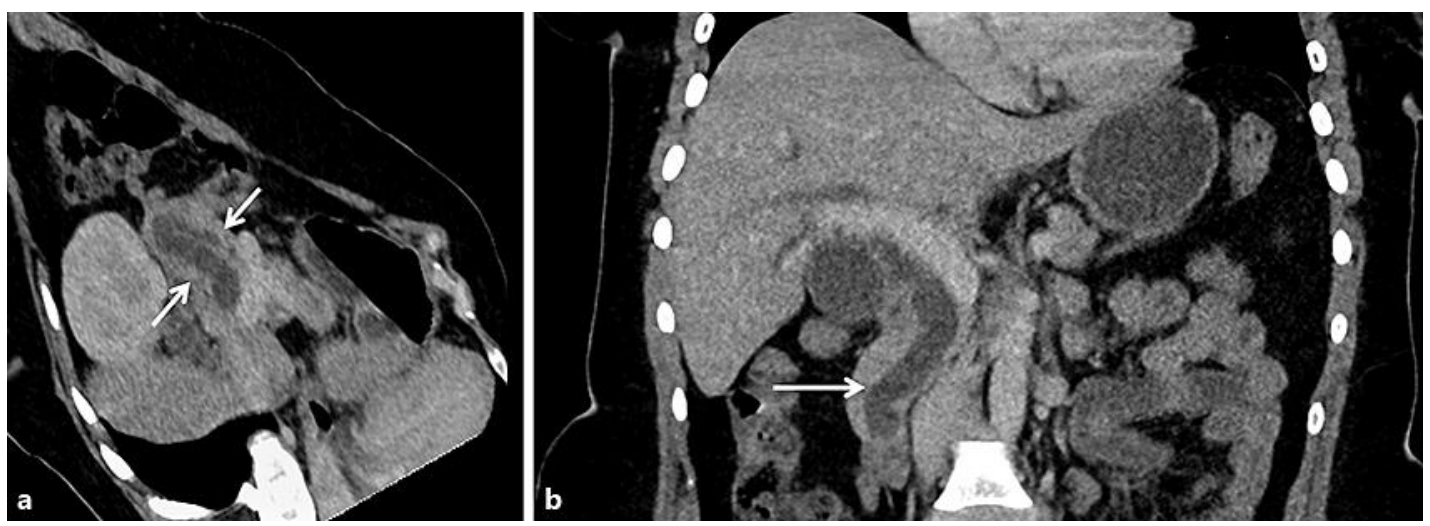

Fig. 1. CT image with adjusted plane showing a double duct sign (a) and a dilated common bile duct (b). 


\section{Case Reports in Gastroenterology}
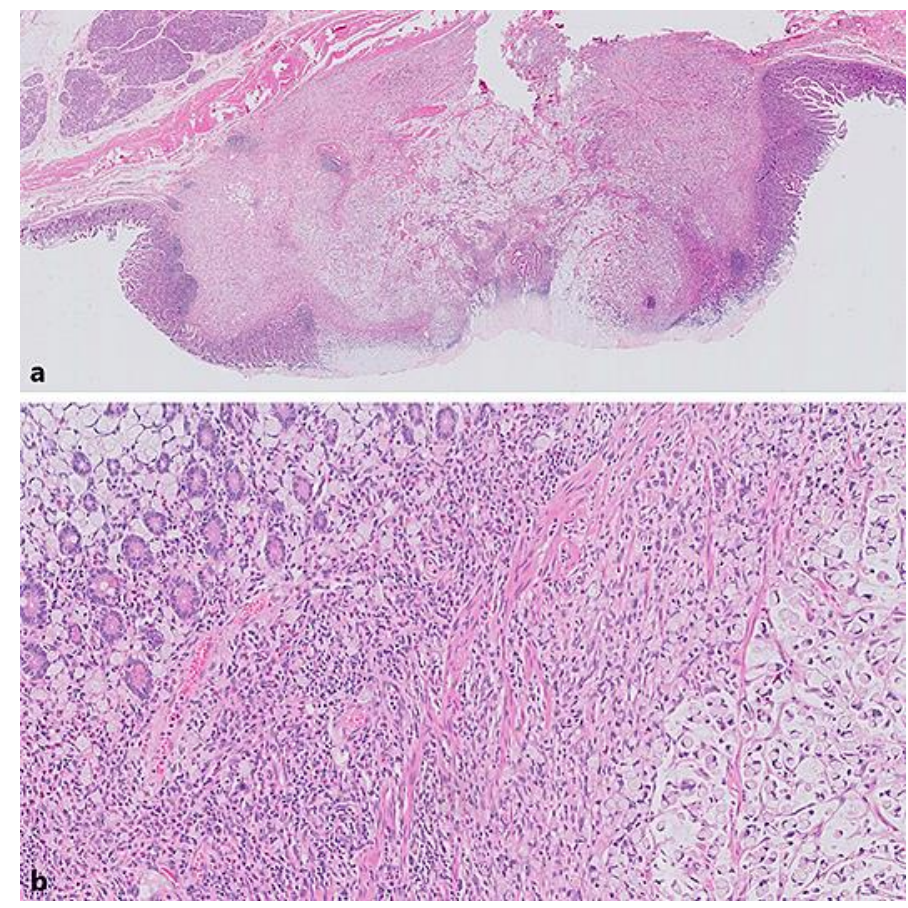

Fig. 2. a Low-power view of the ampullary tumor, infiltrating in the mucosa, submucosa, and inner muscularis propria of the duodenum. HE. $\times 20$. $\mathbf{b}$ High-power magnification, showing preexisting duodenal crypts (right) and submucosa (right) infiltrated by signet ring cells. HE. $\times 200$. 


\section{Case Reports in Gastroenterology}

Case Rep Gastroenterol 2018;12:194-201

(c) 2018 The Author(s). Published by S. Karger AG, Basel DOI: $10.1159 / 000488903$ www.karger.com/crg

de Klein et al.: Signet Ring Cell Carcinoma of the Ampulla of Vater
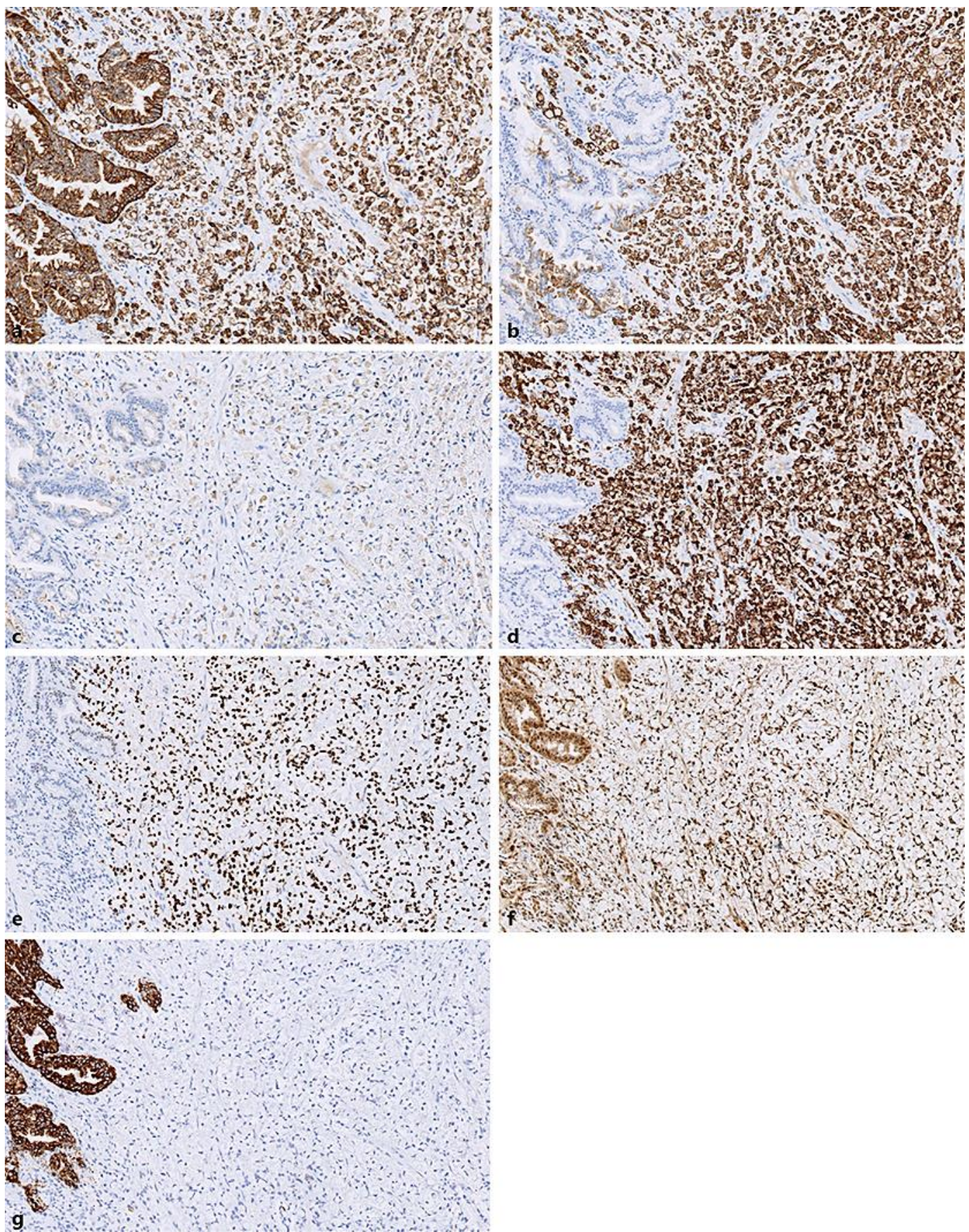

Fig. 3. Immunohistochemical staining of the ampullary tumor, with benign tissue on the left border of each image. Positive staining for CK-19 (a), CK-20 (b), MUC-1 (c), MUC-2 (d), CDX-2 (e), DPC-4 (f), and negative for MUC-5ac (g). 
 Gastroenterology}

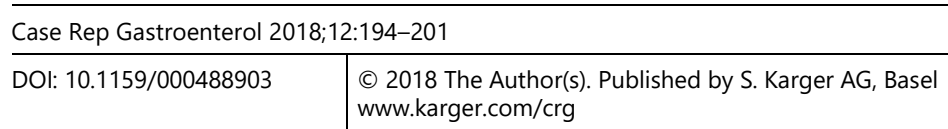
www.karger.com/crg

de Klein et al.: Signet Ring Cell Carcinoma of the Ampulla of Vater

Table 1. Case reports of signet ring cell carcinoma of the papilla of Vater in the English literature sorted chronologically

\begin{tabular}{|c|c|c|c|c|c|c|c|c|}
\hline First author & Year & $\begin{array}{l}\text { Age, } \\
\text { years }\end{array}$ & Sex & $\begin{array}{l}\text { Size, } \\
\mathrm{mm}\end{array}$ & TNM & Treatment & $\begin{array}{l}\text { Follow-up, } \\
\text { months }\end{array}$ & Outcome \\
\hline Gardner [16] & 1990 & 69 & $\mathrm{~F}$ & 20 & T3N0M0 & PD & - & - \\
\hline Hara [15] & 2002 & 68 & M & 15 & T2N0M0 & PPPD & 10 & Alive \\
\hline Tseng [17] & 2002 & 47 & M & 20 & T3N0M0 & PD & 6 & Alive \\
\hline Eriguchi [18] & 2003 & 83 & M & 15 & T3N0M0 & PD & 18 & Alive \\
\hline Li [19] & 2004 & 56 & $\mathrm{~F}$ & 15 & T2N1M0 & PD & 12 & Alive \\
\hline Ramia [20] & 2004 & 67 & $\mathrm{~F}$ & 18 & T2N0M0 & PD & 12 & Alive \\
\hline Fang [21] & 2004 & 53 & M & 26 & T2N0M0 & PD & 25 & Alive \\
\hline Bloomston [22] & 2005 & 58 & $\mathrm{~F}$ & 10 & T2N0M0 & PD & 134 & Alive \\
\hline Akasu [23] & 2007 & 43 & $\mathrm{~F}$ & 20 & T2N0M0 & PD & 90 & Alive \\
\hline Gao [24] & 2009 & 38 & $\mathrm{~F}$ & 20 & T3N0M0 & PD & 6 & Alive \\
\hline Ishibashi [25] & 2009 & 59 & M & 30 & T3N0M0 & PD & 18 & Died \\
\hline Gheza [26] & 2011 & 66 & M & - & - & $\mathrm{PD}$ & 8 & Alive \\
\hline Paplomata [27] & 2011 & 45 & $\mathrm{~F}$ & 30 & T4N1Mx & $\begin{array}{l}\text { PPPD adjuvant } \\
\text { chemotherapy }\end{array}$ & 12 & Died \\
\hline Maekawa [28] & 2011 & 75 & M & 20 & T3N0M0 & PD & 6 & Died \\
\hline Lesquereux-Martínez [29] & 2012 & 78 & $\mathrm{~F}$ & 11 & TxN1M0 & $\begin{array}{l}\text { PD adjuvant } \\
\text { chemotherapy }\end{array}$ & 14 & Alive \\
\hline Daoudi [30] & 2012 & 55 & M & - & T3N0M0 & $\begin{array}{l}\text { PD adjuvant } \\
\text { chemotherapy }\end{array}$ & 8 & Alive \\
\hline Acharya [31] & 2013 & 78 & $\mathrm{~F}$ & 30 & T3N0M0 & PD & 6 & Alive \\
\hline Wen [5] & 2014 & 40 & $\mathrm{~F}$ & 30 & T3N0M0 & PD & 8 & Alive \\
\hline Wen [5] & 2014 & 64 & $\mathrm{~F}$ & 65 & T4NxM0 & PD & 76 & Alive \\
\hline Wen [5] & 2014 & 75 & $\mathrm{~F}$ & 35 & T4NxM0 & PD & 16 & Died \\
\hline Wen [5] & 2014 & 62 & M & 24 & TxN1M0 & PD & 27 & Died \\
\hline Wen [5] & 2014 & 62 & M & 30 & TxN1M0 & PD & 9 & Died \\
\hline Wen [5] & 2014 & 53 & $\mathrm{M}$ & 12 & T3N0M0 & PD & 45 & Alive \\
\hline Wen [5] & 2014 & 66 & $\mathrm{~F}$ & 15 & T3N0M0 & PD & 54 & Alive \\
\hline Wen [5] & 2014 & 68 & M & 95 & T4NxM0 & PD & 72 & Alive \\
\hline Wakasugi [10] & 2015 & 59 & $\mathrm{~F}$ & 20 & T3N1M1 & $\begin{array}{l}\text { PD adjuvant } \\
\text { chemotherapy }\end{array}$ & 7 & Alive \\
\hline Ushida [9] & 2017 & 82 & $\mathrm{~F}$ & 22 & T3N0M0 & PD & 60 & Alive \\
\hline Our case & 2017 & 45 & $\mathrm{~F}$ & 12 & T2N0M0 & PPPD & 12 & Alive \\
\hline
\end{tabular}

F, female; M, male; PD, pancreatoduodenectomy; PPPD, pylorus-preserving pancreatoduodenectomy. 